\title{
Biosynthesis of Silver Nanoparticle by Amphiroa anceps (Lamarck) Decaisne and Its Biomedical and Ecological Implications
}

Roy $\mathbf{S}^{*}$ and Anantharaman $\mathbf{P}$

Faculty of Marine Sciences, Centre of Advanced Study in Marine Biology, Annamalai University, Annamalai Nagar, Tamilnadu, India

\begin{abstract}
The present study synthesized silver nanoparticles by using seaweed extract and tested it against clinical bacterial pathogens and also with seeds to assess its friendly potential to germination. The biosynthesized Silver Nanoparticles was characterized with UV-Visible Spectrophotometer, Fourier-Transform Infrared Spectroscopy (FT-IR), Scanning Electron Microscopy (SEM), Dynamic Light Scattering (DLS) and X-ray Diffraction study. Antibacterial activity was evaluated using agar disc diffusion and the seed germination test was done with standard protocol. The nanoparticles exhibited highest antibacterial activity against Escherichia coli $(0.95 \pm 0.057 \mathrm{~cm})$, followed by Klebsiella pneumoniae $(0.63 \pm 0.05 \mathrm{~cm})$, as compared to antibiotic Chloramphenicol $(5 \mathrm{mg} / \mathrm{ml})$. The per cent seed germination was $75 \%$ and $80 \%$ respectively in Abelmoschus esculentus and Raphanus sativus var. longipinnatus treated with nanoparticles, while it was only in a range of 20 to $40 \%$ in control seeds treated with normal water, seaweed extract and seaweed liquid bio-fertilizer. The antibacterial activity of the biosynthesized Silver Nanoparticle is needed more detailed investigation for its biomedical application. The potential of bio-nano-fertilizer is to be assessed for the whole plant life cycle up to quality and quantity of vegetable yield
\end{abstract}

Keywords: Biosynthesis; Silver nanoparticles; Amphiroa anceps; Antibacterial activity; Seed germination potential

\section{Introduction}

Generally, seaweeds, the marine renewable resource are known for their potential as therapeutics, food, fodder and bio-fertilizer. Globally, seaweeds are exploited as the raw material for various industrial products, but they are not yet extensively exploited for nanoparticle biosynthesis and its medicinal and pharmaceutical utilizations. There are limited studies available on the synthesis of silver nanoparticle by some seaweeds and its potential as antibacterial and antiproliferative $[1,2]$, antifungal [3,4] and anticancer [5-8]. But all work did for a potentiality test of seaweeds against various diseases but some of them only tested for their clinical trial and next for medicine preparation. Although antibacterial activity of some seaweeds are known against human normal and multidrug resistant pathogens, it is required to find out the best potent seaweed for synthesis of Silver Nanoparticle and its potential against the human pathogens.

Silver nanoparticle synthesized with Sargassum plagiophyllum is reportedly stimulating seed germination in Vigna mungo, Arachis hypogaea, and Vigna radiate [9]. Similarly silver nanoparticle synthesized with Caulerpa racemosa and Ulva lactuca induced cucumber seed germination than water, seaweed extract and seaweed liquid fertilizer. It also inhibits the growth of some human pathogens [10]. Some other seaweed also is also reported to have better potentiality for seeds germination [10-12]. But there are more than 841 seaweeds reported from the Indian coast, likewise so many crops and vegetable seeds are available in our market. There is a need of much more study on the effect of seaweed synthesized Silver Nanoparticle on seed germination, in present context of ensuring environmental safety against the toxicity effect of using chemical fertilizers. This work has focused on the red seaweed Amphiroa anceps, synthesized silver nanoparticles to test its effect on seed germination of two important vegetables.

\section{Materials and Methods}

\section{Biosynthesis of silver nanoparticles}

Seaweed extracts preparation: The red seaweed, Amphiroa anceps was collected from Rameshwaram, Olaikuda $\left(09^{\circ} 18^{\prime} .390^{\prime} \mathrm{N}\right.$ and $079^{\circ} 20^{\prime} .076^{\prime}$ E) Gulf of Mannar (Figure 1) and identified with available standard taxonomic key (Figure 2). The extract of fresh seaweed was prepared according to the method followed by Roy et al. [11,12].

Synthesis of Ag-nanoparticles: The aqueous extract of seaweed and Silver Nitrate aqueous solution were used for biosynthesis of Silver Nanoparticles [11,12]. The colour change indicated the biosynthesis of Silver Nanoparticles [13].

Characterization of biosynthesized silver nanoparticles: The biosynthesized Silver Nanoparticles was characterized with UV-2600 SHIMADZU UV-Visible Spectrophotometer, Perkin Elmer FTIR model 2000, Scanning Electron Microscope (JEOL JSM-5610LV) according to the methods mentioned $[11,12]$. The biosynthesized Silver Nanoparticles was also characterized with Dynamic Light Scattering (DLS) analysis and XRD measurements.

Dynamic light scattering (DLS) analysis: The charges on the surface of Nanoparticles dispersed in solution are known as Zeta potential. Due to these surface charges Nanoparticles attract the opposite charged particles and the oppositely charge particles form a thin double layer of ions around the particles which produce an electrical potential which is measured as zeta potential. The zeta potential values greater than $+25 \mathrm{mV}$ or less than $-25 \mathrm{mV}$ indicate the highly stable Silver Nanoparticles. The dynamic light scattering was used to predict the stability of synthesized Silver Nanoparticles by seaweed. In our study, Malvern Zeta potential was estimated for the synthesized Silver Nanoparticles.

${ }^{*}$ Corresponding author: Suparna Roy, Faculty of Marine Sciences, Centre of Advanced Study in Marine Biology, Annamalai University, Annamalai Nagar, Tamilnadu, India, Tel: 919600252681; E-mail: suparna09roy@gmail.com

Received: March 07, 2018; Accepted: March 29, 2018; Published: April 03, 2018

Citation: Roy S, Anantharaman P (2018) Biosynthesis of Silver Nanoparticle by Amphiroa anceps (Lamarck) Decaisne and Its Biomedical and Ecological Implications. J Nanomed Nanotechnol 9: 492. doi: 10.4172/2157-7439.1000492

Copyright: @ 2018 Roy S, et al. This is an open-access article distributed under the terms of the Creative Commons Attribution License, which permits unrestricted use, distribution, and reproduction in any medium, provided the original author and source are credited. 
Citation: Roy S, Anantharaman P (2018) Biosynthesis of Silver Nanoparticle by Amphiroa anceps (Lamarck) Decaisne and Its Biomedical and Ecological Implications. J Nanomed Nanotechnol 9: 492. doi: 10.4172/2157-7439.1000492

XRD measurements: The dried biosynthesized Silver Nanoparticles were sprayed on cuvette and measured under BRUKER D8 ADVANCE POWDER X-ray diffractometer. The samples were analysed from 20 to $80^{\circ} \theta$ (theta) range and the operating voltage was $20 \mathrm{KV}$.

Antimicrobial activity: The antimicrobial activity was tested according to standard method [11,12] and with little modification [3,14-19].

Test on seeds germination: The seed germination potential of Abelmoschus and Raphanus with treatment of biosynthesized Silver Nanoparticles was investigated according to standard protocol $[2,11,12,15,16,19-21]$.

Statistical analysis: The triplicates of zone of inhibition for antibacterial activity were taken and standard deviation was calculated.

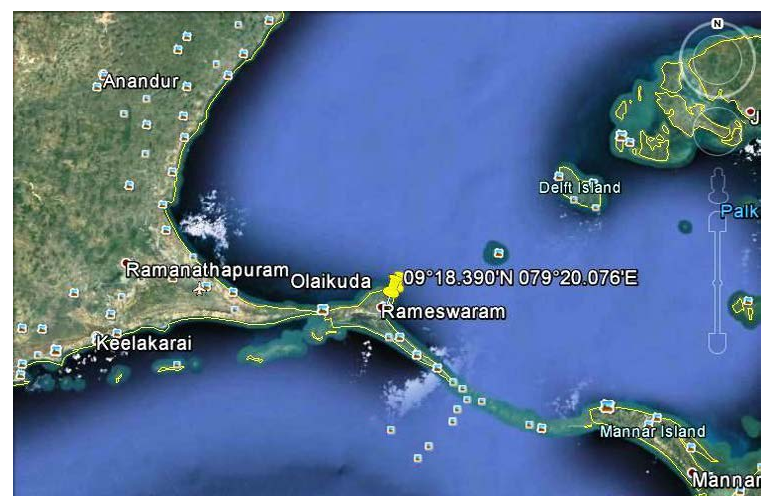

Figure 1: Map showing the sampling location.

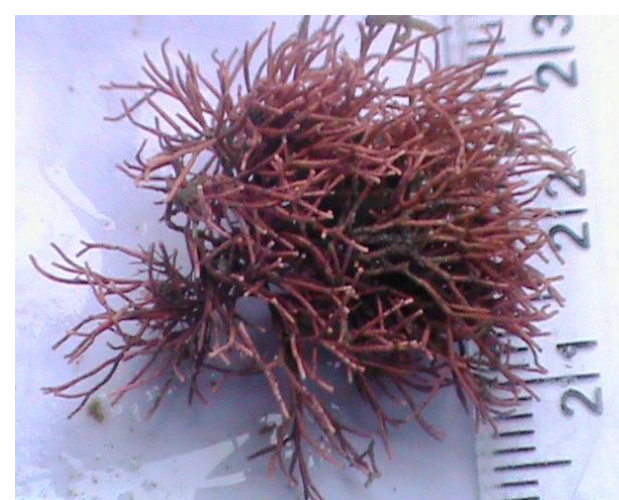

Figure 2: Showing seaweed Amphiroa anceps, (Division-Rhodophyta, ClassRhodophyceae, Order - Corallinales, Family - Corallinaceae).Biosynthesis and characterization of Silver Nanoparticles by Amphiroa anceps.

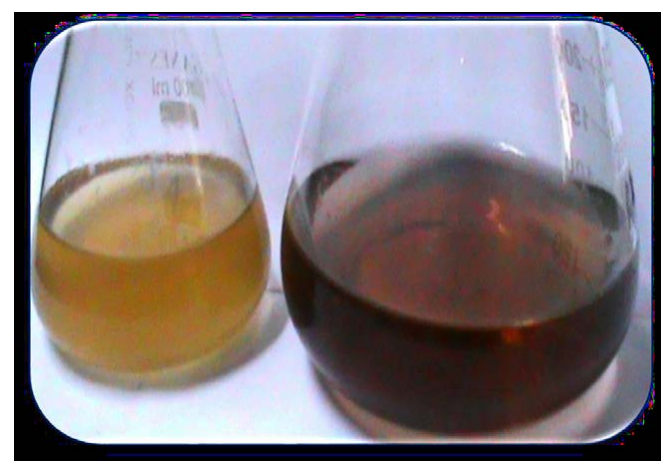

Figure 3: Showing the biosynthesis of Silver Nanoparticles.

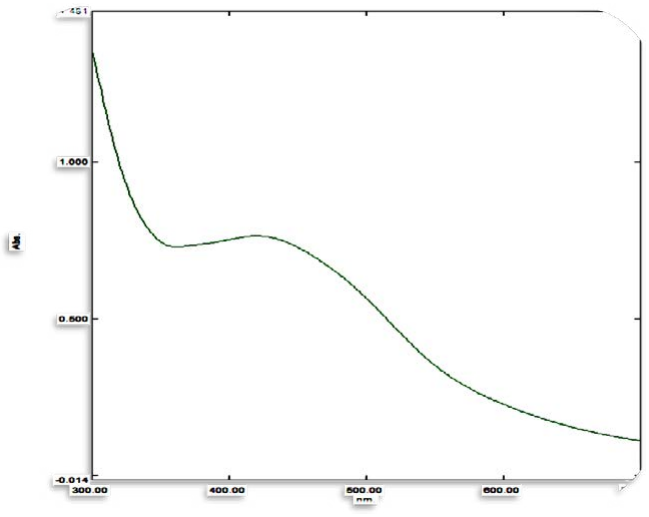

Figure 4: Showing UV-Visible spectrum for biosynthesized Silver Nanoparticles.

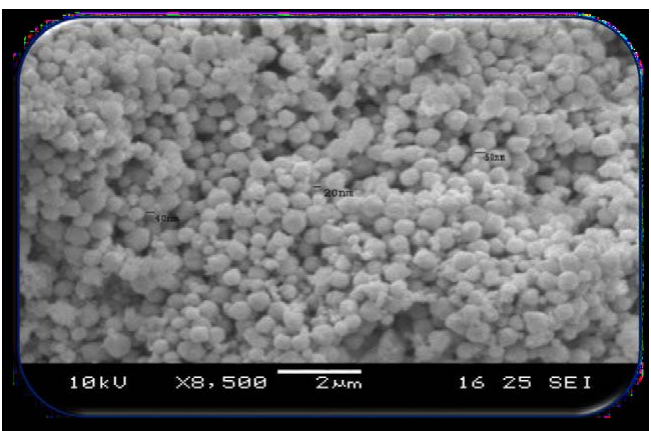

Figure 5: Showing SEM image of biosynthesized Silver Nanoparticles.

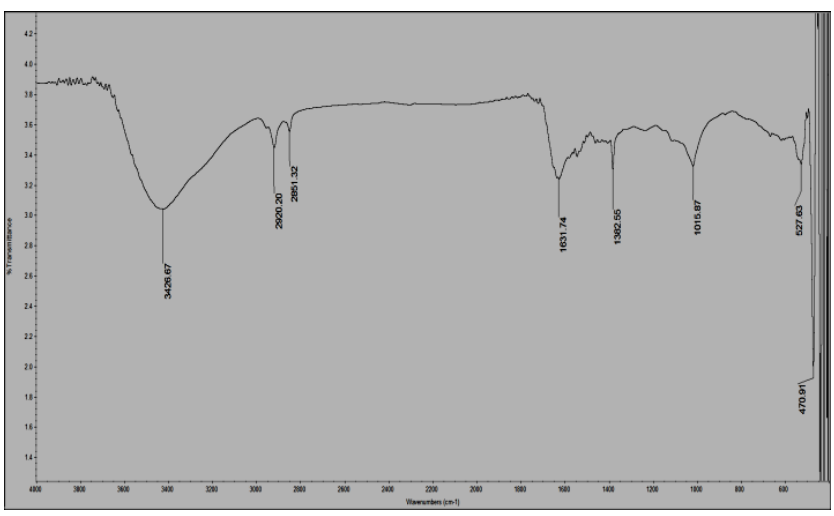

Figure 6: Showing FT-IR spectrum of aqueous extract.

\section{Results and Discussions}

\section{Biosynthesis and characterization of silver nanoparticles}

The colour change of the mixed solution from white to dark reddish brown after shaking indicated biosynthesis of Silver Nanoparticle (Figure 3). The broad stretch at $420 \mathrm{~nm}$ indicated the biosynthesis of Silver Nanoparticle (Figure 4). The Scanning Electron Microscopic images showed clear, well distributed, and spherical Silver Nanoparticle. The size ranged from 10 to $80 \mathrm{~nm}$ (Figure 5). The FTIR spectrum of biosynthesized nanoparticle showed some broad and narrow peaks which were developed due to the vibrations stretches in the presence of the specific functional groups which indicated the existence of the compounds assigned to that particular functional group. The broad bends at $3426.67 \mathrm{~cm}^{-1}, 2920.20 \mathrm{~cm}^{-1}$ and 2851.32 
Citation: Roy S, Anantharaman P (2018) Biosynthesis of Silver Nanoparticle by Amphiroa anceps (Lamarck) Decaisne and Its Biomedical and Ecological Implications. J Nanomed Nanotechnol 9: 492. doi: 10.4172/2157-7439.1000492

Page 3 of 5

$\mathrm{cm}^{-1}$ clearly revealed the presence of amide $(\mathrm{N}-\mathrm{H})$, amine $(\mathrm{N}-\mathrm{H})$ and alcohol $(\mathrm{O}-\mathrm{H})$ groups and accordingly, alkanes $(\mathrm{C}-\mathrm{H})$ and acid $(\mathrm{O}-\mathrm{H})$ and aldehydes $(\mathrm{C}=\mathrm{O})$ functional groups. The stretches were produced at $1631.74 \mathrm{~cm}^{-1}$ for alkenes, $1382.55 \mathrm{~cm}^{-1}$ for nitro, $1015.87 \mathrm{~cm}^{-1}$ for ester and alkyl functional groups (Figure 6). The aqueous extract of seaweed also analysed for FTIR, the spectrum showed a clear peak at $3643.44 \mathrm{~cm}^{-1}$ indicated the presences of alcohol or phenol, and the free stretch of $\mathrm{OH}$ group. Some peaks at $1651.50 \mathrm{~cm}^{-1}, 1557.49$ $\mathrm{cm}^{-1}$ and $1505.60 \mathrm{~cm}^{-1}$ existed due to the functional groups such as alkenes (C-C) group, nitro (N-O) group (Figure 7). The spectrum of biosynthesized Silver Nanoparticles clearly indicated the existence of more functional groups which may responsible for acceleration of seed germination and seedling growth. The present investigation on biosynthesized Silver Nanoparticles with Dynamic Light Scattering explained that the synthesized Silver Nanoparticle was very stable with zeta potential of $(-86.7 \mathrm{mV})$ (Figures 8 and 9). The peaks produced in X-ray Diffractometer spectrum demonstrated the formation of spherical biosynthesized Silver Nanoparticles as the peaks have broader base and the narrower apex which indicated the presence of reduced crystal size Silver Nanoparticles. The observed peaks were found at $2 \theta$

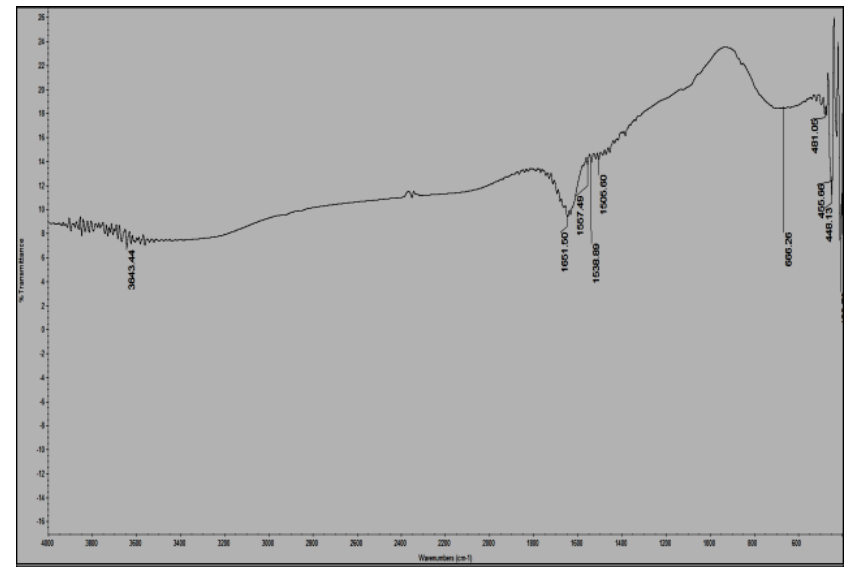

Figure 7: Showing FT-IR spectrum of biosynthesized Silver Nanoparticles.

Results

$\begin{array}{rllll} & & \text { Size (d.nm): } & \text { \% Intensity: } & \text { St Dev (d.n.. } \\ \text { Z-Average (d.nm): } 289.7 & \text { Peak 1: } & 270.4 & 100.0 & 91.71 \\ \text { Pdl: } 0.364 & \text { Peak 2: } & 0.000 & 0.0 & 0.000 \\ \text { Intercept: } 0.876 & \text { Peak 3: } & 0.000 & 0.0 & 0.000 \\ \text { Result quality : Good } & & & & \end{array}$

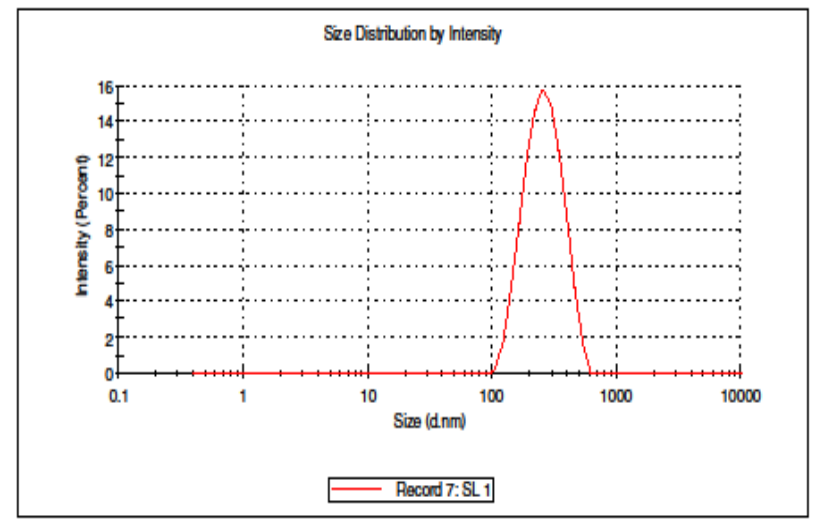

Figure 8: Showing the size distribution.

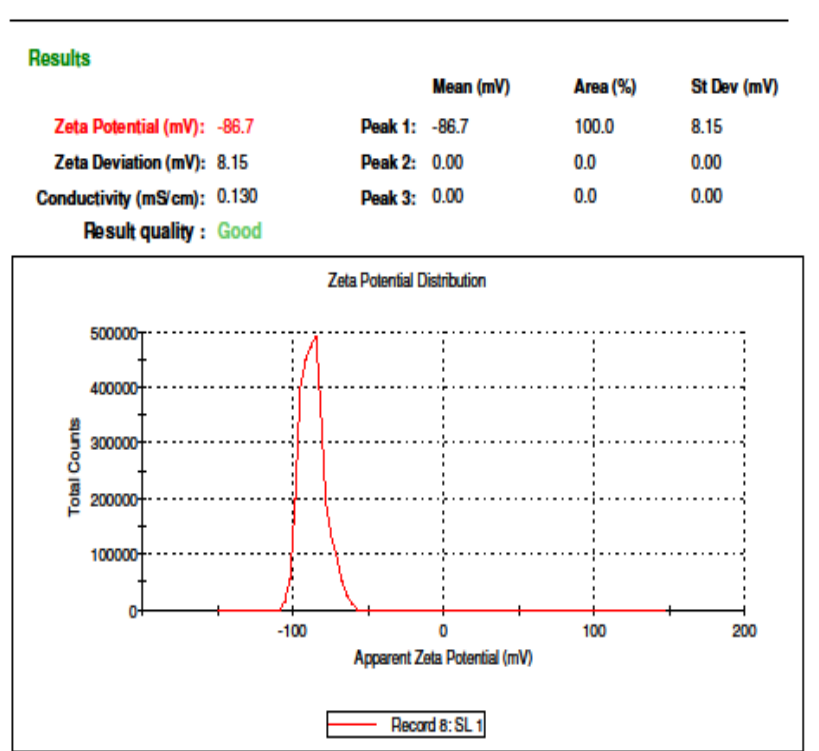

Figure 9: Showing the zeta potential.

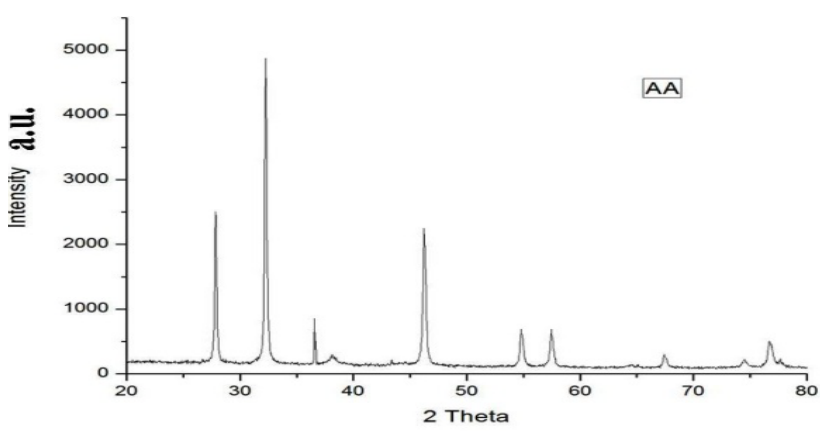

Figure 10: Showing the XRD pattern of biosynthesized Silver Nanoparticles.

values at $28.50^{\circ}, 33.50^{\circ}$ and $46.25^{\circ}$. The estimated grain size (D) was $32.25 \mathrm{~nm}$. The equation used for analysis of the grain size as followed: $\beta=\pi / 180 \times$ width $(\mathrm{x}) ; \mathrm{D}=\mathrm{k} \lambda / \beta \cos \theta(\mathrm{nm}) . \mathrm{X}=0.21246,2 \theta=33.50^{\circ}$ (Figure $10)$. The size difference of nanoparticles in measurement of SEM and EDX was differing due to agglomeration.

\section{Test for seed germination potential}

Test for seeds of Abelmoschus esculentus: In case of treatment with biosynthesized Silver Nanoparticles to Abelmoschus seeds, the seed germination, germination index and relative root elongation were 571.42, 374.04 and 280 respectively (Figure 11a). After 96 hours of treatment with biosynthesized Silver nanoparticle, $80 \%$ of seed germinated and the percentage of seeds germination was increased with increase of time (Figure 11b). After 96 hours of treatment, mean germination time was 1.6 hours, it also increased with increase of time (Figure 11c). All the analysed parameters of seed germination were higher in the case of seeds treated with biosynthesized silver nanoparticles as compared to the seeds treated with normal water, seaweed extract and seaweed liquid bio-fertilizer (Figure 11d-11f).

Test for seeds of Raphanus sativus var. longipinnatus: In the case of Raphanus seeds, after 24 hours of treatment, the relative root elongation was 650 with the germination index of 1300 (Figure 12a). The seed germination ranged from $80 \%$ to $85.71 \%$ with variation of 
Citation: Roy S, Anantharaman P (2018) Biosynthesis of Silver Nanoparticle by Amphiroa anceps (Lamarck) Decaisne and Its Biomedical and Ecological Implications. J Nanomed Nanotechnol 9: 492. doi: 10.4172/2157-7439.1000492
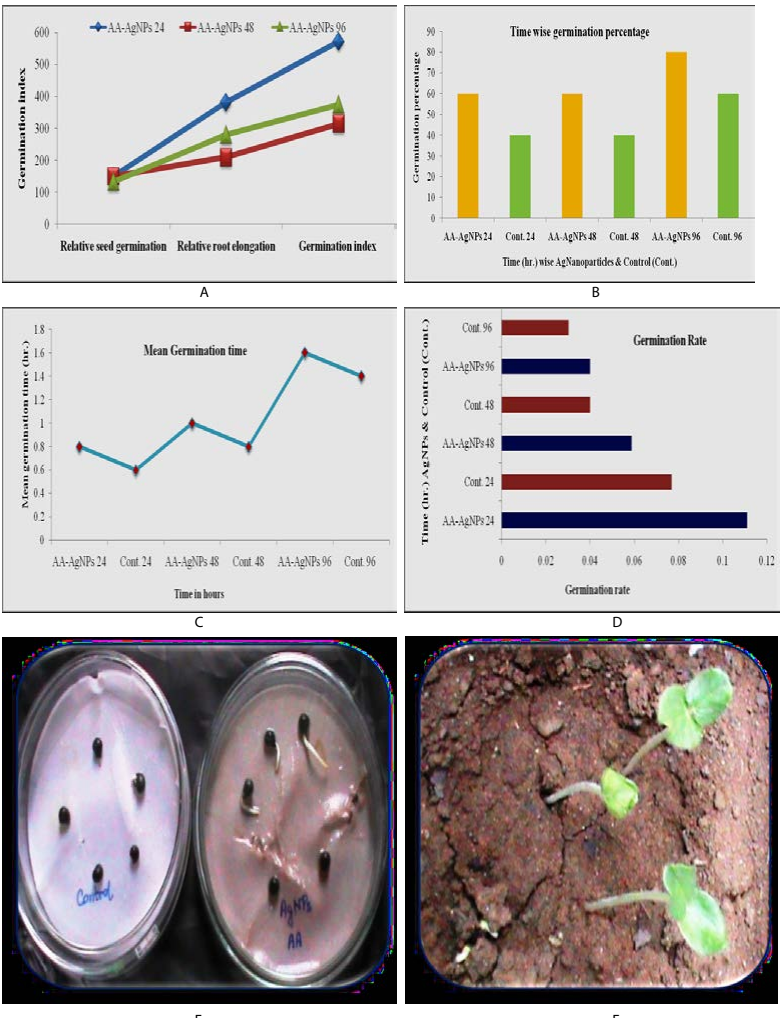

Figure 11: Effect of biosynthesized Silver Nanoparticles on seed germination of Abelmoschus esculentus. (a) Seed germination index (b) Seed germination percentage (c) Mean seed germination time (d) Seed germination rate (e) Seed germination (f) Seedlings of radish.
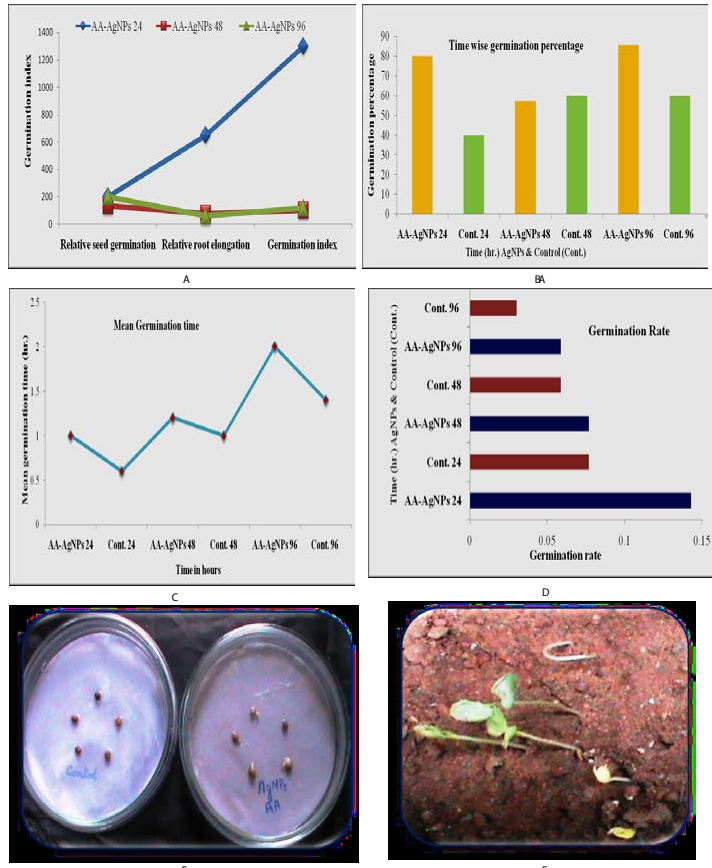

Figure 12: Effect of biosynthesized Silver Nanoparticles on seed germination of Raphanus sativus var. Iongipinnatus. (a) Seed germination index (b) Seed germination percentage (c) Mean seed germination time (d) Seed germination rate (e) Seed germination (f) Seedling of radish.
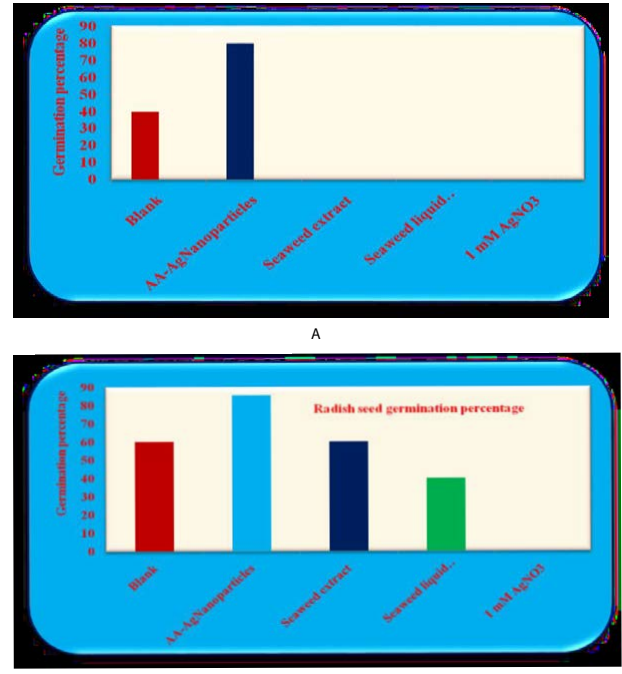

Figure 13: Effect of silver nitrate solution, seaweed liquid fertilizer and seaweed extract on ladies finger and radish seed germination: (a) Showing seed germination percentage of ladies finger (b) Seed germination percentage of radish

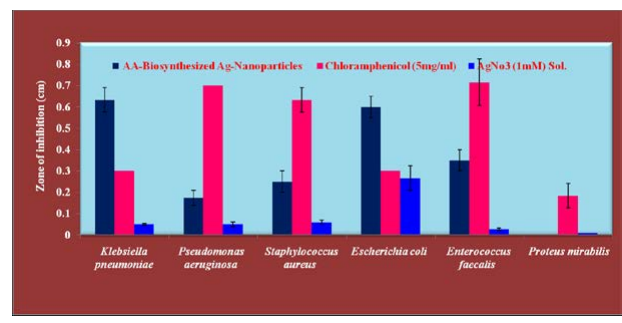

Figure 14: Showing the zone of inhibition of biosynthesized Silver Nanoparticles (Amphiroa anceps), antibiotic and silver nitrate.

time duration (Figure 12b). The seed germination rate was 0.14 seed/ hours for the seeds treated with seaweed synthesized nanoparticles (Figure 12c). The analysed seed germination parameters were the highest for nanoparticles treated seeds (Figure 12d-12f).

Test of both seeds with treatment of silver nitrate solution, seaweed liquid fertilizer and seaweed extract: Both seeds did not germinate with the treatment of solution of $1 \mathrm{mM} \mathrm{AgNO}_{3}$. The seeds of Abelmoschus and Raphanus germinated at $80 \%$ and $85.71 \%$ respectively with seaweed based nanoparticle, whereas they germinated at $40 \%$ and $60 \%$ with normal water treatment. The Abelmoschus seeds did not germinate with seaweed extract and seaweed liquid biofertilizer, but Raphanus seeds germinated $60 \%$ with treatment of water and seaweed extract, similarly $40 \%$ seeds germinated when treated with seaweed liquid bio-fertilizer (Figure 13a and 13b). The biosynthesized silver nanoparticle from the fungus Trichoderma harzianum is earlier shown to have positive effect on seed germination of Helianthus annus (Sunflower) and Glycine max (Soybean). It has also been recorded that seeds which soaked longer time in biosynthesized silver nanoparticle has increased the seeds viability and germination [22-25]. The seeds have been reported to germinate at $80 \%$ and $75 \%$ of Abelmoschus and Raphanus respectively with the treatment of Chaetomorpha antennina biosynthesized silver nanoparticles. But, seed germination is reported only 20 to $40 \%$ for water, seaweed extract and seaweed liquid biofertilizer treatment $[11,12]$. Similarly silver nanoparticle synthesized by the brown seaweed Sargassum ilicifolium is shown to induce germination of seeds [17]. 
Citation: Roy S, Anantharaman P (2018) Biosynthesis of Silver Nanoparticle by Amphiroa anceps (Lamarck) Decaisne and Its Biomedical and Ecological Implications. J Nanomed Nanotechnol 9: 492. doi: 10.4172/2157-7439.1000492

Assay for antibacterial activity: The silver nanoparticle was tested against six common human clinical pathogens and found the highest inhibitory activity against Escherichia coli $(0.95 \pm 0.057 \mathrm{~cm})$ followed by Klebsiella pneumoniae $(0.63 \pm 0.05 \mathrm{~cm})$, as compared to control, Chloramphenicol $(5 \mathrm{mg} / \mathrm{ml})$ and $1 \mathrm{mM}$ Silver Nitrate solution. But no significant effect was found against Proteus mirabilis (Figure 14). Similar to this, a previous study has used another red seaweed Pterocladiella capillacea mediated biosynthesize of silver nanoparticles, which exhibits inhibitory effect on some human pathogenic bacteria such as Staphylococcus aureus, Bacillus subtilis, Pseudomonas aeruginosa and Escherichia coli [2]. It has reported that the Sargassum cinereum synthesized silver nanoparticle has high inhibition against the growth of Enterobacter, Salmonella typhi and Proteus vulgaris [1]. The inhibitory activity however is reportedly only $10 \%$ against Pseudomonas aeruginosa, Salmonella abony, Listeria monocytogenes and Enterococcus faecalis in the methanol extract of Enteromorpha spirulina, Chondrus crispus, Palmaria palmata, Laminaria digitata, Laminaria saccharina, and Himanthalia elongata [3]. Some researchers have also reported antibacterial and antioxidant activity of selected seaweeds $[5,6,13]$. The inhibition of biosynthesized silver nanoparticle by red seaweed Acanthophora specifera is found to be significant against Bacillus subtilis, Escherichia coli, Staphylococcus aureus and Salmonella spp. $[23,24]$. The biosynthesized silver nanoparticle from Turbinaria conoides is found to have toxic effect on Bacillus subtilis and Klebsiella planticola and with high zone of inhibition [14].

\section{Conclusions}

It is concluded form the study that, the silver nanoparticle of high stability and functional groups such as amine amides and aromatic compounds can be synthesized by using red seaweed extract. The green synthesized nanoparticle is stimulating seed germination of both studied vegetables, and it is also highly toxic against some pathogenic bacteria. Further studies are required on the biomedical and agricultural applications of the nano bio fertilizer.

\section{Acknowledgements}

Authors are sincerely thankful Prof. Dr. K. Kathiresan, D.Sc. BSR-Scientis Former Dean \& Director, C.A.S in Marine Biology, Faculty of Marine Sciences, Annamalai University. We are very much thankful to the higher authorities of Annamalai University. We are thankful to Head of the Department of Microbiology, Physics and Chemistry and the staff members for providing some research facilities for this study. We are thankful to Dr. P. Kumar, Assistant Professor, Department of Animal Health and Management 6th Floor, Science Campus for some analysis. Our Sir sincere thanks to the Dean, Faculty of Marine Sciences, and the Director, Centre of Advanced Study in Marine Biology, Faculty of Marine Sciences, Annamalai University for their support to complete the work successfully.

\section{References}

1. Mohandass C, Vijayaraj AS, Rajasabapathy R, Satheeshbabu S, Rao SV, et al (2013) Biosynthesis of Silver Nanoparticles from Marine Seaweed Sargassum cinereum and their Antibacterial Activity. Indian J Pharm Sci 75: 606-610.

2. Yassin El Kassas H, Attia A (2014) Bactericidal application and cytotoxic activity of biosynthesized silver nanoparticles with an extract of the red seaweed Pterocladiella capillacea on the HepG2 cell line. Asian Pacific Journal of Cancer Prevention 15: 219-235.

3. Kumar P, Senthamil S, Selvi M, Govindaraju P (2013) Seaweed-mediated biosynthesis of Silver Nanoparticles using Gracilaria corticata for its antifungal activity against Candida spp. Appl Nanosci 3: 495-500.

4. Marimuthu V, Palanisamy SK, Sesurajan S, Sellappa S (2011) Biogenic Silver Nanoparticles by Gelidiella acerosa extract and their antifungal effects. AJMB 3: $365-371$.
5. Devi S, Bhimba BV (2012) Anticancer Activity of Silver Nanoparticles Synthesized by the Seaweed Ulva lactuca In-vitro J. Scientific Reports 4: 231-237.

6. Khalifa KS, Hamouda RA, Hanafy D, Hamza A (2016) In vitro antitumor activity of Silver Nanoparticles biosynthesized by marine algae. Digest Journal of Nanomaterials and Biostructures 1: 213-221.

7. Venkatesan J, Kim SK, Shim MS (2016) Antimicrobial, antioxidant, and anticancer activities of biosynthesized silver nanoparticles using marine algae Ecklonia cava. Nanomaterials (Basel) 6: 235-243.

8. Selvi BCG, Madhavan J, Santhanam A (2016) Cytotoxic effect of Silve Nanoparticles synthesized from Padina tetrastromatica on breast cancer cell line. Adv Nat Sci Nanosci Nanotechnology 7.

9. Mary XA, Mathuran T, Saji M, Kumar SA (2015) In-vitro germination effect of biologically synthesized Silver Nanoparticles from Sargassum plagiophyllum on Arachis hypogaea, Vigna mungo, and Vigna radiate. International Research Journal of Natural and Applied Sciences 12: 278-284.

10. Aravindan D, Azeez R, Nallamuthu T (2014) Biosynthesis of Silver Nanoparticles using two seaweeds and their potential towards environment. Nano Biomed Eng 4: 123-132.

11. Roy S, Anantharaman P (2017) Green Synthesis of Silver Nanoparticles by Sargassum Cinctum J. Agardh and their Potential for Seed Germination. IJTSRD 1: 321-329.

12. Roy S, Anantharaman P (2017) Biosynthesis of Silver Nanoparticles by Chaetomorpha antennina (Bory de Saint-Vincent) Kutzing with its antibacterial activity and ecological implication. Journal of Nanomedicine \& Nanotechnology 8: 2-9.

13. Kannan RRR, Stirk WA, Van Staden J (2013) Synthesis of silver nanoparticles using the seaweed Codium capitatum P. C. Silva (Chlorophyceae). South African Journal of Botany 86: 1-4.

14. Barrena R, Casals E, Colón J, Font X, Sánchez A, et al. (2009) Evaluation of the eco-toxicity of model Nanoparticles. Chemosphere 75: 850-857.

15. Singaravelu G, Arockiyamari J, Kumar GV, Govindaraju K (2007) A novel extracellular biosynthesis of monodisperse Gold Nanoparticles using marine algae, Sargassum wightii Greville. Colloids and Surfaces B: Biointerfaces 57: 97-100.

16. Taga MS, Miller EED, Pratt K (1984) Chia seeds as a source of natural lipids antioxidants. J Am Oil Chem Soc 61: 928-993.

17. Thakkar KN, Mhatre SS, Parikh RY (2010) Biological synthesis of metallic nanoparticles. Nano Medicine 6: 257-262.

18. Gonzalez Del Val A, Platas G, Basilo A, Cabello A, Gorrochategui J, et al (2001) Screening of antimicrobial activities in red, green and brown macro algae from Gran Canaria (Canary Islands, Spain). International Journal of Microbiology 4: 35-40.

19. Roy S, Anantharaman P (2018) Biosynthesis of Silver Nanoparticles by Sargassum llicifolium (Turner) C. Agardh with their antimicrobial activity and potential for seed germination. Journal of Applied Physics \& Nanotechnology 1: 1-9.

20. Cox S, Abu-Ghannam N, Gupta S (2010) An assessment of the antioxidant and antimicrobial activity of six species of edible Irish seaweeds. International Food Research Journal 17: 205-220.

21. Ganesan P, Kumar CS, Bhaskar N (2008) Antioxidant properties of methano extract and its solvent factions obtained from selected Indian red seaweeds. Bio Resource Technology 99: 2717-2723.

22. Plaza M, Santoyo S, Jaime L, García-Blairsy Reina G, Herrero M, et al. (2009) Screening for bioactive compounds from algae. J Pharm Biomed Anal 20: 741-751.

23. Ibraheem IBM, Abd Elaziz BEE, Saad WF, Fathy WA (2016) Green Biosynthesis of Silver Nanoparticles using marine red algae Acanthophora specifera and its antimicrobial activity. J Nanomed Nanotechnol 7: 2-4.

24. Kumar S, Kannan C, Annadurai G (2012) Green synthesis of silver Nanoparticles using marine brown algae Turbinaria conoides and its antibacterial activity. Int $J$ Pharm Bio Sci 3: 502-510.

25. Gitanjali H, Ashok C (2015) Synthesis, characterization and stability of gold nanoparticles using the fungus Fusarium oxysporum and its impact on seed germination. International Journal of Recent Scientific Research 6: 3181-3185. 